\title{
Socio-economic Development and its Impact on Health Personnel in Regions of Visegrad Group Plus Countries
}

\section{Ingrid Majerová ${ }^{1}$}

\begin{abstract}
The quality of life and economic development of economies and their regions is influenced by socio-economic indicators such as unemployment, healthcare and education, environmental issues or household equipment. The question remains whether these indicators within regions can also influence each other and whether they have positive or negative effects. The paper aims to describe the impact of the selected socioeconomic indicators on health personnel, which was also divided from the gender perspective. For this purpose, the regions of the Visegrad Group Plus countries at NUTS II level were selected. The research was performed in the period from 2004 to 2013. According to our results based on the Generalized Method of Moments with panel data, we found out that a change in household income and a change in the number of vehicles in the monitored regions have the greatest (positive) impact on staff in hospitals. The research may contribute to the discussion about levels of regional economic development and the related competitiveness in terms of the socio-economic approach, and it may also provide a basis for further discussion on its measurement and use of appropriate indicators.
\end{abstract}

Key words: countries of Visegrad Group Plus, Generalized Method of Moments, health personnel, socio-economic indicators

JEL Classification: C33, O15, R11

Received: 12 June 2018 / Accepted: 30 November 2018 / Sent for Publication: 18 March 2019

\section{Introduction}

Quality of life can be measured through socio-economic indicators such as income, level of health, technological infrastructure, educational system, public safety or the approach to ecological problems. As Rovan and Sambt (2003) have clarified, the socioeconomic issue among regions is of primary interest to economists as well as politicians. Differences in the level of the socio-economic indicators should be maintained within sustainable limits for the sake of the welfare of the country as a whole. The analysis of

\footnotetext{
${ }^{1}$ Silesian University in Opava, School of Business Administration in Karvina, Univerzitni nam. 1934/3, 73340 Karvina, Czech Republic, majerova@opf.slu.cz.
}

(C) 2019 by the authors; licensee Review of Economic Perspectives / Národohospodářský obzor, Masaryk University, Faculty of Economics and Administration, Brno, Czech Republic. This article is an open access article distributed under the terms and conditions of the Creative Commons Attribution 3.0 license, Attribution - Non Commercial - No Derivatives. 
these indicators may serve as the basis for development policy on the regional level. The difference between regions and countries is not always very clear, but the major distinction in most cases is the fact that (in contrast to countries) regions are open spatial entities, and that the competence of a region may normally be superseded by the nations (Nijkamp and Abreu, 2009).

The main motivation for writing this paper is based on the idea of Christian et al. (1977). They claimed that socio-economic development is an integrated process: the health sector interacts with other sectors of the socio-economic system. It is impossible to effectively plan for health care without considering the circular causation between health and the other socio-economic sectors. A similar claim was also made by Zurn et al. (2004), namely that economic, sociodemographic, cultural, and geographical factors contribute to shaping and transforming society and hence have a direct or indirect impact on health workforce issues. According to WHO (2016b), targeted investment in health systems, including in the health workforce, promotes economic growth along with other pathways: economic output, social protection and cohesion, innovation and health security. The High-Level Commission on Health Employment and Economic Growth of World Health Organisation (WHO, 2016a) finds that health workforce investments coupled with the right policy action could unleash enormous socio-economic gains in quality education, gender equality, decent work, inclusive economic growth, and health. Semyonov et al. (2013) founded a positive relationship between wealth and health applies in 16 examined countries, based on socio-demographic attributes and household income.

The aim of this paper (based on the above motivation) is to estimate the impact of the socio-economic development (through selected indicators) on health personnel, both female and male. For this reason, we decided to analyse this issue for a group of countries of the Visegrad Group Plus (hereafter V4+) at the NUTS II level. This group includes the Visegrad Group countries (Czech Republic, Hungary, Poland and Slovakia) and Slovenia and Austria. These last two mentioned economies were included in this group by the Regional Partnership Agreement in 2001. There are 46 regions on the NUTS II level - eight in the Czech Republic, seven in Hungary, sixteen in Poland, nine in Austria, four in Slovakia and two in Slovenia. The data were obtained for the period from 2004, which was the first year of EU membership of five of the six countries surveyed, to 2013, when the last data for all indicators and regions are available.

Ten indicators were selected to measure the impact of socio-economic development in the regions of the aforementioned V4+ economies. Two economic indicators, i.e., household income and unemployment, one environmental, i.e., municipal waste, three health variables, i.e., infant mortality, health personnel and hospital beds, and four indicators of standard of living, i.e., stock of vehicles, motorways, beds in tourist accommodations and nights spent at tourist accommodation establishments. As the health sector is a growing employer of women, and it can greatly contribute to gender equality (WHO, 2016b), we decided to examine the impact of individual indicators also from a gender perspective - by dividing both women and men.

The selection of the indicators mentioned above was influenced not only by previous research in which the authors confirmed, although not quite definitively, certain linkages among some of the indicators (see next section), but also by the authors' belief in 
their interrelations. Last but not least, the selection of these indicators was influenced by their availability at the regional level. The measurement at a national level is less problematic in this case - data of GNI per capita, waste policy, school enrolment, environmental variables, etc. are accessible in databases, unlike regional data. As we tried to cover a wide range of socio-economic indicators and their impacts, we selected all available indicators in the Eurostat database in the selected countries/regions and in the given period.

These mentioned variables will be used in two steps of the Generalized Method of Moments (from now on GMM method) to establish a correlation between the number of health personnel and other socio-economic indicators. A dynamic panel model was used then - firstly to find links and relationships between indicators in regions where the essence of this type of method is not to examine each subject (region) separately but as a whole, and secondly in order to reduce the statistical problems of regressions estimated by ordinary least squares (OLS). Further, a dynamic panel setting allows controlling for the region-specific effects, the omitted variable bias and the endogeneity of explanatory variables.

Even if this paper is not the first attempt to study the relationships of the socioeconomic indicators at the regional level in V4(+) countries, it differs from the existing literature in using the influence of these indicators on the numbers of health personnel and complex concepts of the given issue in the GMM method at the mentioned regional level. Majerova (2018) constructed a composite index of regional development of V4 countries using the min-max model. She has incorporated the indicator of health personnel as one of 12 variables of index. Majerova and Nevima (2017) focused on the analysis of socio-economic development in V4+ countries using the cluster Ward method and divided the regions to three groups according to the potential for development. Verner and Chudarkova (2013) have dealt with the relationship of human capital (including the health personnel) and economic growth in Visegrad group countries and considered that increases in human capital will tend to economic growth and thus will contribute to the improvement of national competitiveness. We hoped that our research could be able to complement the studies concerning the measurement of socioeconomic development.

The rest of the paper is organized as follows: Section 2 presents us with a brief literature review, Section 3 gives information about the sample and used variables, Section 4 describes the model and methodology used in the paper. Section 4 discusses the results in detail, and Section 5 concludes the paper.

\section{Literature Review}

This section analyses various studies of relationships of socio-economic indicators and works with an application of the Generalized Method of Moments in the socioeconomic field in terms of time.

Michaud and van Soest (2008) claimed that in many industrialized countries, there is a positive association between health and wealth. On the other hand, population health tends to improve with the country's level of economic development (Semyonov et al. 2013). Health, like education, is a fundamental component of human capital and leads to 
economic growth. Health improvements tend to reduce the mortality rates of infants (Bloom and Canning, 2003). According to Anand and Bärnighausen (2004), the strong relevance between health personnel and infant mortality exists in more than 80 countries. Shafik (1994) found that an increasing income corresponds with the increased waste generation which represents deterioration in the quality of life. Eugenio-Martin et al. (2004) claim that tourism provides two positive effects on the economy: on the one hand, an increase in production and income; on the other hand, as the tourism sector is labour intensive, it increases employment. Thus, the tourism sector may contribute significantly to both economic growth and employment in these regions. Jalan and Ravallion (1998) focused on the effects of poor-area development programs on the standard of living in the selected regions of China. Their applied consumption-growth model also suggests that households living in the areas targeted by the program had a higher rate of the consumption growth than one would have otherwise expected. Mullahy and Sindelar (1996) analysed the relationships between health problems and unemployment. They claim that misuse of alcohol results in enormous economic costs, composed largely of a reduced labour market productivity. They found out, based on the data about the US population (approximately 150 thousand), that for both men and women, the problem of drinking (of alcohol) results in reduced employment and increased unemployment. Issa and Ouattara (2005) examined the impact of health expenditure (private and public) and other socio-economic indicators (such as income per capita and education) on infant mortality in 160 countries.

The GMM approach links nicely to an economic theory where orthogonality conditions that can serve as such moment functions arise from the optimizing behaviour of agents. (Imbers, 2002). According to Nielsen (2005), the idea of the GMM is intuitive as well as elegant, and the knowledge of the principle of GMM is very useful for understanding econometrics in general. This method has become an important estimation procedure in many areas of applied economics and finance since Hansen (1982) introduced two steps. We have to mention the work of Arellano and Bond (1991) as well, who used the GMM method with an approach later called Arellano-Bond GMM. They applied this method to estimate employment equations using an unbalanced panel of 140 quoted UK companies for the period from 1979 to 1984. Halkos (2003) applied the Arellano-Bond approach in his study to test empirically the hypothesis of the inverted U-shaped relationship between the environmental damage from sulphur emissions and economic growth as expressed by GDP, using a large database of panel data consisting of 73 OECD and non-OECD countries over a period of 31 years (1960-1990).

Davis and Quinlivan (2006) used the GMM to analyse the impact of trade on 154 countries' social developments as measured by the Human Development Index, in the period from 1975 to 2002. They argue that the relationship between per-capita trade and human development will follow a distributed lag pattern. Following the "indirect effect" argument above, the improvements in trade will result in some immediate income gains. These gains will, in turn, result in future increases in literacy and health as the people's standards of living rise and the opportunities for returns on education increase. Direct gains in human development result from exposure to foreign goods (particularly medical and health related products). Zhang and Zhuang (2011) examined the effect of the composition of human capital on economic growth in 31 provinces in China over the period 1997-2006, using the Generalized Methods of Moments (GMM) method. The results show that tertiary education plays a more important role than primary and sec- 
ondary education in economic growth in China. Moreover, the role of the accumulation of human capital in the regional economic growth is relevant to the level of development. More developed provinces benefit more from tertiary education, while underdeveloped ones depend more on primary and secondary education.

Comber et al. (2011) analysed the relationship between public perceptions of access to general practitioners (GPs) surgeries and hospitals against health status, car ownership and geographic distance in the UK county of Leicestershire. They claimed that the impacts of bad health and non-car ownership on the difficulties experienced in accessing health services varied spatially across the area, while the impacts of geographic distance did not.

Geishecker (2012) analyses the impact of the perceived job insecurity on current subjective well-being among the German population based on previous research. He found that the consistently estimated effect of perceived job insecurity is more than twice the size of the conventional estimates, and ignoring simultaneity between the perceived job insecurity and individual well-being drastically underestimates the negative impact of job insecurity perceptions.

$\mathrm{Ng}$ et al. (2013) used the GMM dynamic panel data model to address the reverse causality and potential endogeneity issues. The result reveals that broadband penetration appears to be the key factor in the explanation of Gross Domestic Product growth and suggests that the utilization of broadband infrastructure and its application is expected to enhance the national aggregate outputs. Croissant et al. (2013) use the GMM to detect the relationship between allotment and reducing public transport costs in 141 French urban public transport networks, without increasing the competition and declining returns to scale.

Saidi and Hammami (2015) investigated economic and environmental issues, namely the impact of the economic growth and $\mathrm{CO}_{2}$ emissions on energy consumption for a global panel of 58 countries using the dynamic panel data model estimated using the GMM in the period from 1990 to 2012. They also estimate this relationship for three regional panels, namely from Europe and North Asia, Latin America and the Caribbean, and sub-Saharan Africa, North Africa and the Middle East. The empirical evidence indicated a significant positive impact of $\mathrm{CO}_{2}$ emissions on energy consumption and economic growth in energy consumption which is statistically significant only for the four panels, except the Middle East.

Clayton et al. (2015) found a relationship between aggregate household debt and aggregate health outcomes (such as life expectancy at birth, various causes of death and disorders) across 17 European countries in the period from 1995 to 2012. Using a dataset of the country-level standardized and objective measures of household debt, health outcomes and a rich set of control variables, the authors estimated an instrumental variable GMM model to address possible reverse causality concerns. They used education, real GDP per capita or alcohol consumption as other variables and found that the aggregate household debt affects health outcomes and that this varies according to the maturity of the debt. Both short and medium-term debt has a positive effect on health outcomes. Long-term unsecured debt and mortgage debt are associated with poorer health outcomes. Overall, the results suggest that aggregate household debt is an important determinant of aggregate health outcomes across the countries. 
With these cases in mind, we focus in our paper on the potential impact of socioeconomic indicators on the number of health personnel using the sample of all regions in the Visegrad Group Plus countries. Next, we describe our sample and the variables used in the analysis.

\section{Sample and Variables}

As Fingleton (2003) claims, the economic geography of Europe is characterised by wide differences in levels of some socio-economic variables that are both a cause of and a response to differences in the growth and levels of income per capita. This section describes the sample and the indicators that influence and are linked to regional socioeconomic development.

\section{Sample}

We decided to analyse the above-mentioned issue for a group of countries of the Visegrad Group Plus (V4+) at the NUTS II level - including the founding members: the Czech Republic, Hungary, Poland and Slovakia, as well as Slovenia and Austria which later joined this group on the basis of the Regional Partnership Agreement if 2001. There are 46 regions on the NUTS II level - eight in the Czech Republic, seven in Hungary, sixteen in Poland, nine in Austria, four in Slovakia and two in Slovenia. The list of regions in our sample is shown in Table 1 . The data were obtained for the period from 2004 to 2013.

Table 1 List of regions in $\mathrm{V4+}$

\begin{tabular}{|c|c|c|c|c|c|}
\hline Region & $\begin{array}{c}\text { St. } \\
\text { name }\end{array}$ & Region & $\begin{array}{c}\text { St. } \\
\text { name }\end{array}$ & Region & $\begin{array}{c}\text { St. } \\
\text { name }\end{array}$ \\
\hline Praha & CZ01 & Lódzkie & PL11 & Burgenland (AT) & AT11 \\
\hline Střední Cechy & CZO2 & Mazowieckie & PL12 & Niederösterreich & AT12 \\
\hline Jihozápad & $\mathrm{CZO3}$ & Malopolskie & PL21 & Wien & AT13 \\
\hline Severozápad & CZO4 & Slaskie & PL22 & Kärnten & AT21 \\
\hline Severovýchod & CZO5 & Lubelskie & PL31 & Steiermark & AT22 \\
\hline Jihovýchod & CZO6 & Podkarpackie & PL32 & Oberösterreich & AT31 \\
\hline Střední Morava & $\mathrm{CZO7}$ & Swietokrzyskie & PL33 & Salzburg & AT32 \\
\hline Moravskoslezsko & CZ08 & Podlaskie & PL34 & Tirol & AT33 \\
\hline $\begin{array}{l}\text { Közép- } \\
\text { Magyarország }\end{array}$ & HU10 & Wielkopolskie & PL41 & Vorarlberg & AT34 \\
\hline Közép-Dunántúl & HU21 & Zachodniopomorskie & PL42 & Bratislavský kraj & SK01 \\
\hline Nyugat-Dunántúl & HU22 & Lubuskie & PL43 & Západné Slovensko & SK02 \\
\hline Dél-Dunántúl & HU23 & Dolnoslaskie & PL51 & Stredné Slovensko & SK03 \\
\hline Észak-Magyarország & HU31 & Opolskie & PL52 & $\begin{array}{l}\text { Východné Slov- } \\
\text { ensko }\end{array}$ & SKO4 \\
\hline Észak-Alföld & HU32 & Kujawsko-Pomorskie & PL61 & Vzhodna Slovenija & SI01 \\
\hline Dél-Alföld & HU33 & $\begin{array}{l}\text { Warminsko-Mazurskie } \\
\text { Pomorskie }\end{array}$ & $\begin{array}{l}\text { PL62 } \\
\text { PL63 }\end{array}$ & Zahodna Slovenija & $\mathrm{SIO}$ \\
\hline
\end{tabular}

Source: Eurostat (2018). 


\section{Description of variables}

The annual data were obtained from the Eurostat regional database (Eurostat, 2018), with regional data for NUTS I to III. The selection of indicators was rather limited because of data availability for all regions of the EU and for each level of classification.

We focused on ten available regional socio-economic variables that were assigned codes and units which can be found in Table 2. There are two economic indicators (income of households and unemployment), one environmental (municipal waste), three health variables (infant mortality, health personnel and hospital beds) and four indicators of the standard of living (stock of vehicles, motorways, beds in tourist accommodations and nights spent at tourist accommodation establishments). As stated earlier, these indicators were chosen because we were interested, based on previous studies, whether there are any relationships between them.

\section{Table 2 Socio-economic indicators and their codes}

\begin{tabular}{lcc} 
Indicator & Code & Unit \\
\hline Income of households & IN & per capita \\
Unemployment rate & UN & $\%$ of active inhabit. \\
Municipal waste & WS & per 1000 inhab. in tones \\
Infant mortality & DC & per 100,000 inhabit. \\
Health personnel & HE & total persons \\
Hospital beds & HB & per 100,000 inhabit. \\
Stock of vehicles & VH & per capita \\
Motorways & MW & total in km \\
Beds in tourist accommodations & TB & per 10,000 inhabit. \\
Nights spent in a tourist accommodation establish- & NT & total amount \\
ment & & \\
\hline Source: & &
\end{tabular}

Source: authors' own processing.

Our focus was their relationship to the healthcare staff, particularly from the perspective of gender. We are convinced that the level of income has a positive effect on the number of healthcare professionals - the richer the population, the better they can take care of their health, increasing not only the quality but also the quantity of healthcare staff. On the other site (according to Smith, 1999), poor health may restrict a peoples' capacity to earn income or to accumulate assets by limiting work or by raising medical expenses (to pay for medicines or a doctor's visit). Another relationship is the inverse relationship between the rate of unemployment and the number of medical staff - the higher, the less healthcare population is employed. According to WHO (2016b) the health sector is a key economic sector and a job generator, f. e. across the OECD countries, employment in health and social work grew by $48 \%$ between 2000 and 2014 . Healthcare produces a lot of waste, Berwick and Hackbarth (2012) claim that there are more than $20 \%$ of total health care expenditures in U. S. It is therefore very likely that with a growing number of health personnel, the sector will produce more waste and thus place a greater burden on the environment and regional budgets (due to the specific type of such waste produced it is difficult to dispose of). The direct relationship between infant mortality and health personnel has been already mentioned and we agree - the density of health personnel significantly influence not only infant mortality but children and mother ones in all UN members countries as well (Muldoon et al., 2011). Another 
indicator - hospital beds - has a positive link to health care staff, the more doctors and nurses there are, the greater the increase in the capabilities and capacities of healthcare facilities which can take in more patients to stay there. There is extensive evidence that reductions in hospital capacity affect remaining staff members adversely (McKee, 2004). The stock of vehicles, and the associated network of motorways can also positively influence the number of healthcare personnel by allowing for better and faster availability of the services provided by these staff. It is also highly probable that more cars and more high-speed ways are connected with an increasing number of health personnel, particularly in cases of the increased incidence of injuries. The relationship between beds in tourist accommodations and nights spent in them may appear to be illogical at first sight, but it is important to bear in mind two things - firstly the risk and likelihood of injuries and the need for treatment increases with the increasing number of tourists (and their decision to stay in a particular place). Secondly (and more surprising) is a new kind of real estate market - according to King (2012) with U.S. newbuild hotel development at a near standstill, one of the few that niches where new properties continue to get built are the hospital-adjacent hotel market. He claims that nine of Concord's 81 hotels serve medical centers, including hospitals such as the Houston Medical Center and the University of Pittsburgh Medical Center. Moreover, about $20 \%$ of the hotels in the company's development pipeline are either adjacent to or near medical centers. More hotel/hospital patients who can be treated, require more medical staff. All the above-said was the reason why we assume that there is also the possibility of mutual relationships here.

In the process of selecting these kinds of variables, we had to take into account the fact that some of them are not available at the regional - NUTS II level. Thus our selection was limited. All variables are applied to the period from 2004 to 2013, the first year of EU membership and last year of data availability.

"Income of households" (IN) in PPS per inhabitant represents the disposable income that every citizen in the monitored region is able to spend per year. Purchasing Power Standards (PPS) are fictive currency units that remove differences in purchasing power, i.e. different price levels between countries. These parities are obtained as a weighted average of relative price ratios in respect to a homogeneous basket of goods and services, both comparable and representative for each country (Majerova, 2017).

The indicator of "Unemployment" (UN) by sex, age in NUTS II regions represents all inhabitants 15 years old or over and is expressed as a percentage of all inhabitants. This indicator (if its level is high) has a lot of negative effects on regional development - it is a social problem connected with effects on economic activities.

Among the environmental indicators included was the quantity of waste produced. This variable reflects the differences in the economic wealth between the regions - wealthier regions usually generate more municipal waste per capita. In this paper, "Municipal waste" (WS) expresses the total waste per thousand inhabitants in tons. Municipal waste consists of waste collected by municipal authorities, or directly by the private sector (business or private non-profit institutions) not on behalf of municipalities. The bulk of the waste stream originates from households, though similar wastes from sources such as commerce, offices, public institutions, and selected municipal services are included 
as well. It also encompasses bulky waste, but excludes waste from municipal sewage networks and municipal construction and demolition waste (Majerova, 2018).

"Infant mortality" (DC) per 100,000 inhabitants describes the rate of death of live-born infants who have not reached the age of one year. Regional differences in infant mortality may reflect the differences in wealth and spending on healthcare. In this case, the infant mortality rate can be a measure of the health and social condition of the region. It is a composite of many component rates, all of which have their own separate relationships with various social factors and thus can often be seen as an indicator to measure the level of socio-economic diversity within regions.

The number of health personnel and hospital beds has a positive correlation with socioeconomic development. "Health personnel" indicator (HE) includes all people that are active in the health care sector (doctors, physicians, dentists, nursing and caring professionals, pharmacists, physiotherapists, etc.), irrespective of the sector of employment (i.e. whether they are independent or employed by a hospital or any other healthcare provider).

"Hospital beds" (HB) available per 100 thousand inhabitants is another indicator related to the health sector. It includes available beds in hospitals and subcategories (such as curative care beds, psychiatric care beds, etc.) and available beds in nursing and residential care facilities as well as medical technology and technical resources in hospitals (for people requiring ongoing health and nursing care due to chronic impairments and reduced degrees of independence in activities of daily life).

The indicators of the standard of living connected with the level of regional development are the stock of vehicles, the number of motorways and nights spent in tourist establishments. In our case, the "Stock of vehicles" (VH) represents all vehicles (except trailers and motorcycles) per inhabitant in the mentioned regions. The indicator of "Motorways" (MW) describes roads specially designed and built for motor traffic, which do not serve properties bordering on them and which have no crossings at the same level with any road, railway or tramway track, or footpath, and are especially sign-posted as a motorway and are reserved for specific categories of road motor vehicles (United Nations, 1983).

Tourism is generally regarded to play a major role in bringing about social change. It certainly exerts a very important economic, productive, and cultural influence (Pérez and Nadal, 2005). Tourism plays an important role in solving economic and social problems, providing more jobs, stimulating employment growth among the economically active population and increasing the welfare of the nation, while at the same time having a stimulating effect on the development of many related fields of the economic activity - it contributes to the socio-economic development (Gabdrakhmanov and Rubtsov, 2014). For this reason, two variables were included in the group of socioeconomic indicators. The first variable „Number of bed-places” (TB) is calculated per ten thousand inhabitants and is determined by the number of persons who can stay overnight in the beds set up in the establishment (dwelling), ignoring any extra beds that 
may be set up at customer request. ${ }^{2}$ The second variable "Nights spent at tourist accommodation establishments" (NT) is calculated by country of the residence of the guest and by month.

\section{Model and Methodology}

The purpose of this paper is to investigate the impact of the selected socio-economic indicators on health personnel (both female and male) empirically using a dynamic panel model. Although the panel regression examines the selected population as a whole, it can show some common features of socio-economic development of V4+ regions. As was mentioned above, the majority of previous studies have been devoted to the analysis of a narrow range of these indicators. Thus a more comprehensive analysis will be made in this paper.

\section{Descriptive analysis}

Given that the selected indicators had different bases (per capita, percentage, units, 10,000 or 100,000 citizens, see Table 2), the data had to be recalculated in order to be comparable. Two recalculations were performed - firstly conversion to the same base, namely to per inhabitant (further referred to as "per capita"), secondly the recalculation for the total population of the region was made, further referred to as "all citizens". We assume, this division shows better impact on individual indicators.

When testing the interdependence of the indicators, a statistical significance test of $1 \%$, $5 \%$ and $10 \%$ level was performed. It was found that some of the proposed indicators are statistically insignificant, namely the indicators of unemployment rate (UN), motorways (MW) and nights spent at tourist accommodation establishment (NT). For this reason these indicators were excluded from further research, and we only worked with seven variables to determine our aim: health personnel (HE), income of households (IN), waste (WS), infant mortality (DC), hospital beds (HB), number of vehicles (VH) and bed places in tourist establishments (TB).

Table 3 presents descriptive statistics for the selected significant variables, or, rather, for their growth rate in the monitored period. We note that the average growth rate of households' income is $4 \%$, and the development in the amount of vehicles and number of bed places (both more than 3\%) is very positive. These indicators thus show a growing standard of living. We also note, on average, a positive development in infant mortality that declined by more than $3.7 \%$ and at the same time only a weak increase in average production of waste $(0.5 \%)$.

\footnotetext{
${ }^{2}$ The term bed place applies to a single bed, double beds are counted as two bed places. The unit serves to measure the capacity of any type of accommodation. A bed place is also a place on a pitch or in a boat on a mooring to accommodate one person. One camping pitch should equal four bed places if the actual number of bed places is not known (Eurostat, 2018).
} 
Table 3 Descriptive Statistics

\begin{tabular}{ccccccc} 
& Mean & Median & Maximum & Minimum & Std. Dev. & Observations \\
\hline IN & 4.0159 & 4.1885 & 21.7337 & -12.6925 & 4.1969 & 414 \\
WS & 0.5701 & 0.4659 & 50.5383 & -56.3641 & 10.5416 & 414 \\
DC & -3.7443 & -4.6623 & 91.6420 & -125.1544 & 25.8137 & 414 \\
HE & 0.5731 & 1.0640 & 27.9480 & -28.3783 & 5.2496 & 414 \\
HB & -0.3335 & -0.4142 & 39.6645 & -40.2442 & 4.4815 & 414 \\
VH & 3.1565 & 2.8023 & 16.2343 & -14.2268 & 3.4926 & 414 \\
TB & 3.1420 & -0.0116 & 116.9107 & -28.8304 & 11.7902 & 414 \\
\hline
\end{tabular}

Source: authors' own processing.

According to the values of the standard deviation which measures the relative difference of the indicators' growth in regions, we note that the spread does not vary widely for them. The greatest deviation among the regions of the Visegrad Group Plus corresponds to the development of the indicator of infant mortality (mostly 26); the second one is the development of beds in tourist establishments (12), and the third biggest deviation is in the growth of waste (11). These three components are the most heterogeneous. In the development of the rest of the variables, there is a small dispersion (between 3.5 and 5.3). From this perspective, the monitored group of countries appears to be homogeneous, without greater volatility and tendencies to risk in the socio-economic sphere.

\section{Model analysis}

We assume observations on a large number of individuals, with several observations on each of them. The model of interest is a regression model in which the lagged value of the dependent variable is one of the explanatory variables. The error in the model contains a time-invariant individual effect as well as random noise. We consider the commonly assumed and empirically relevant case of a large number of individuals and a small number of time series observations per individual. We have therefore used a twostep GMM model with the pooled data and fixed effects (using random effects is not appropriate in this case).

To find out if the time series are cointegrated, i.e. if they contain a common element and develop dependent on themselves, a Johansen Fisher panel cointegration test (in VAR model) was used. This test is used for the whole panel, and in the case of cointegration, the static model is able to catch the long-run behaviour of time series (Artl and Mandel, 2014). The results of this testing are shown in the Appendix and according to low values of probability that equal in most cases to zero, ciontegration was confirmed.

For our research, to express the relationships between the indicators, we based our estimation on the following theoretical equation (1):

$$
y_{i t}=\alpha_{i t}+\beta y_{i,(t-1)}+\beta x_{1 i t}+\ldots+\beta x_{n i t}+\varepsilon_{i t} .
$$


It is always necessary to determine as first which variable is dependent and which variables are then independent. For this purpose, the causality using Granger test was proved. By testing the causality, we have to reject the set null hypothesis that $x$ does not cause $y$ For the purpose of this paper, the health personnel as $y$ variable was chosen. The test rejected the null hypothesis and confirmed that the set of socio-economic indicators influence the health personnel indicator, so the determination of this dependent variable was correct. On the base of it, the more specific equation of our issue is than (2):

$\widehat{H E_{l t}}=\widehat{\alpha_{i t}}+\beta_{0} \widehat{H E}_{i(t-1)}+\beta_{1} \widehat{I N}_{i t}+\beta_{2} \widehat{V H}_{i t}+\beta_{3} \widehat{W S}_{i t}+\beta_{4} \widehat{H B}_{i t}+\beta_{5} \widehat{D C}_{i t}+\beta_{6} \widehat{T B}_{i t}+$ $\widehat{\varepsilon_{l t}}$,

where endogenous variable $H E_{i t}$ means the number of employees from $i$ regions of Visegrad Group Plus countries who work in hospitals in time $t$. Our exogenous regressors are as follows: $I N_{i t}$ which is the income of households, $V H_{i t}$ means the number of vehicles, $W S_{i t}$ is the production of waste, $H B_{i t}$ means the number of beds in hospitals, $D C_{i t}$ is the number of cases of child death, and finally $T B_{i t}$ means the number of beds for tourists in hotels in the regions. The symbol $\alpha_{i t}$ and $\varepsilon_{i t}$ means a constant and residuals.

According to Arellano and Bond (1991) or Akinci et al. (2013) if the model (in our case given by (2)) includes cross-sectional fixed-effects and a lagged dependent variable which is in a panel with a relatively small time-series dimension (in our case $\mathrm{T}=11$ ), it requires the use of a Generalised Method of Moments (GMM) estimation procedure. As the main estimation method, two-step Generalized Method of Moments (GMM) with pooled data and fixed period effects among panels is used, estimated by Heryán and Tzeremes (2017). The selection of this method was done according to Roodman (2009) which claimed, that the two-step efficient GMM performs somewhat better than onestep in estimating coefficients, with lower bias and standard errors. The reported twostep standard errors, with his correction, are quite accurate so that two-step estimation with corrected standard errors seems modestly superior to robust one-step.

We used the two steps GMM model set by Hansen (1982) and used by Bond, Hoeffler and Temple (2001) explained in two procedure. In the first step the weighted matrix W which determines how each moment condition is weighted in the estimation, is equal I (identity matrix). The least squares problem is solved by setting estimator in (3).

$\hat{\theta}^{(1)}=\operatorname{argmin}_{\theta} g_{T}(\theta)^{\prime} g_{T}(\theta)$,

where $\theta^{(1)}$ is the estimator, argmin is the minimal values of $\theta, g_{T}(\theta)$ measures the average sampling error, becomes as close as possible to zero and is equal to $\frac{1}{T} \sum_{t=1}^{T} u_{t}$. $\mathrm{T}$ expresses the number of years (time series dimension) and $\mathrm{u}_{\mathrm{T}}$ covariance stationary vector. In the second step the covariance stationary vector valued function is computed (4) and estimated the covariance matrix (5). 
$\widehat{u_{t}}=u\left(x_{t} ; \widehat{\theta^{(1)}}\right)$

$\widehat{S_{J}}=\frac{1}{T} \sum_{t=j+1}^{T} \widehat{u_{t}} \widehat{u_{t+j}}$

where $x_{t}$ is a vector of variables that are observed at date $t, j=0,1, \ldots \ldots ., l$, where $l$ is the lag length. The long-run covariance matrix is then estimated in (6) with weights $\mathrm{w}_{\mathrm{j}}$, for setting $W=\widehat{S^{-1}}$ and obtaining the second step estimate (7).

$$
\begin{aligned}
& \hat{S}=\hat{S}_{0}+\sum_{j=1}^{l} w_{j}\left(\hat{S}_{j}+\hat{S}_{j}^{\prime}\right) \\
& \hat{\theta}^{(2)}=\operatorname{argmin}_{\theta} g_{T}(\theta)^{\prime} W g_{T}(\theta) .
\end{aligned}
$$

We have estimated four kinds of models. First, models vary due to the variables all examined both for the individual citizen and for the whole population. In the first case they were recalculated per capita (if needed) in absolute amount, in the second case all variables are examined in percentage changes from the first differences of natural logarithms. Second, the models vary for the gender, when only the endogenous variable differs according to the number of employed people among men and women. In this case are the data are logarithms and are differentiated on the 1st and 2nd level.

\section{Results and Findings}

The results of this study are presented in Table 4 and Table 5, where the multicollinearity and also impact of socio-economic variables on health personnel (female and male separately) are tested, and so after exclusion of the variables of the unemployment rate, motorways and nights spent at tourist accommodation establishments that were statistically insignificant. All time series have been then proved as stationary at their first differences using Augmented Dickey-Fuller (ADF test) and Phillips-Perron (PP test).

The problem of multicollinearity among regressors (income of households, number of vehicles, amount of waste, hospital beds, infant mortality and beds in tourist accommodations), has also been rejected according to Table 4. Even though the Spearman correlation coefficients are not statistically significant in all cases, they are in interval values $(-0.8 ; 0.8)$ and no collinearity among them exists.

Using the GMM model, the data were tested in terms of statistical significance, where it was found that statistically significant coefficient occurs only at $1 \%$ or $5 \%$ level and no statistically significant coefficient at $10 \%$ level. In terms of the output of Table 5, we can see that the most significant influence of variables on the development of health personnel is their per capita conversion - there is the health personnel of the previous period, household income, vehicles, infant mortality, and tourist beds. A significant impact on the development of HE indicator has only the amount of waste and hospital beds, in case of conversion to all citizens. 
Table 4 Tests for multicollinearity

\begin{tabular}{ccccccc} 
Indicator & $I N_{i t}$ & $V H_{i t}$ & $W S_{i t}$ & $H B_{i t}$ & $D C_{i t}$ & $T B_{i t}$ \\
\hline$V H_{i t}$ & $0.2957^{* * *}$ & 1.0000 & & & & \\
$W S_{i t}$ & -0.0092 & $0.0789^{*}$ & 1.0000 & & & \\
$H B_{i t}$ & $0.1302^{* * *}$ & 0.0480 & -0.0594 & 1.0000 & & \\
$D C_{i t}$ & -0.0073 & -0.0069 & 0.0651 & 0.0451 & 1.0000 & \\
$T B_{i t}$ & 0.0171 & -0.0390 & $-0.0852^{*}$ & -0.0046 & -0.0442 & 1.0000 \\
\hline
\end{tabular}

For the gender diversion, the number of influencing variables is the same - the number of women in healthcare is affected more by the personnel in the previous year, the number of cars and children mortality. On the other hand, the development of the number of men is more affected by household income, waste and hospital bed.

More specifically, the change in household income $I N_{i t}$ and change in the number of vehicles $V H_{i t}$ in the regions of selected countries V4+ has the greatest impact on staff change in hospitals $H E_{i t}$. In both cases, this is a positive impact, which means that if both quantities are growing by one percentage point (p. p.), the number of staff in hospitals is growing as well (by approx. $12 \mathrm{p}$. p.). The change in the number of employees in hospitals in the previous years $H E_{i(t-1)}$ seems very significant, which is logical - the 1 p. p. of change in number of personnel hospital in the previous period causes the about 33 p. p. change in the monitored period. In this case, however, it is an inverse relationship. Thus, we can claim that if the number of employees increased in the past, it will develop in the opposite direction in the following period, and vice versa.

Two positive, statistically significant links, albeit only third the amount of the level in terms of the estimated coefficients, represent a positive impact of the change in the quantity of waste produced by households $W S_{i t}$ and the change in the number of hospital beds $H B_{i t}$. In the first case the change one percentage point causes the change of $4 \mathrm{p}$. p. of health personnel, in the second case it causes the change of 0.38 p. p. Even in this case, we can see that the links that we found, are valid not only in terms of the whole population's data but also after their conversion per capita.

The importance of the increase in infant mortality $D C_{i t}$ is insignificant regarding the comparison of the value of the coefficient. The impact of changes in the mortality of infants on health personnel is very small - if the number of deaths increase at 1 percentage point, the health personnel rise about $0.45 \mathrm{p}$. p. The monitored regions have a low mortality rate of small children, and therefore there are changes (decreasing) without a significant impact on the number of health personnel.

The tourist indicator - the number of beds in accommodation establishments - has significantly less impact on the number of health personnel. If the number of this kind of beds increases at one percentage point, the health personnel rise about $1.6 \mathrm{p}$. p. The positive impact of the number of tourist beds $T B_{i t}$ has been found to be statistically 
significant only after the indicator's conversion to per capita, in other cases this impact was insignificant.

Table 5 Output of panel GMM models for V4+

\begin{tabular}{lcccc} 
& Per capita & All citizen & Female workers & Male workers \\
\hline$H E_{i(t-1)}$ & $-0.3307^{* * *}$ & $-0.3260^{* * *}$ & $-0.3265^{* * *}$ & $-0.3252^{* * *}$ \\
$I N_{i t}$ & $0.1361^{* * *}$ & $0.1185^{* * *}$ & $0.1177^{* * *}$ & $0.1189^{* * *}$ \\
$V H_{i t}$ & $0.1942^{* * *}$ & $0.1146^{* *}$ & $0.1186^{* * *}$ & $0.1116^{* *}$ \\
$W S_{i t}$ & $0.0406^{* * *}$ & $0.0404^{* * *}$ & $0.0388^{* * *}$ & $0.0422^{* * *}$ \\
$H B_{i t}$ & $0.0381^{* *}$ & $0.0387^{* *}$ & $0.0371^{* * *}$ & $0.0410 b^{* *}$ \\
$D C_{i t}$ & $0.0057^{* * *}$ & $0.0042^{* *}$ & $0.0044^{* * *}$ & $0.0040^{* *}$ \\
$T B_{i t}$ & $0.0155^{* *}$ & & & \\
Period fixed effects 2007 & -0.2795 & -0.2155 & -0.1767 & -0.2572 \\
Period fixed effects 2008 & $-2.2662^{* * *}$ & $-1.9338^{* * *}$ & $-1.9202^{* * *}$ & $-1.9689^{* * *}$ \\
Period fixed effects 2009 & $-0.8080^{* * *}$ & $-0.4922^{* *}$ & $-0.4820 * *$ & $-0.5023^{* *}$ \\
Period fixed effects 2010 & $-0.2512^{* * *}$ & $-0.3517^{* * *}$ & $-0.3534^{* * *}$ & $-0.3507^{* * *}$ \\
Period fixed effects 2011 & $-1.7480^{* * *}$ & $-2.0450^{* * *}$ & $-2.1813^{* * *}$ & $-1.9034^{* * *}$ \\
Period fixed effects 2012 & $-0.4830^{* *}$ & $-0.4312^{* *}$ & $-0.4269^{* *}$ & $-0.4335^{* *}$ \\
Period fixed effects 2013 & -0.2064 & 0.1064 & 0.1390 & 0.0724
\end{tabular}

$\overline{\text { Symbol }}^{* * * *}$ or ${ }^{* *}$ means statistical significant coefficient at $1 \%$ or $5 \%$ level (no statistical significant coefficient at $10 \%$ level).

Source: authors' own processing.

Where there are statistically significant fixed effects over the period, it is a matter of expression of vertical dependence among individual regions in the panels of each of the created variables. We see that the most significant negative effects among the Visegrad Group Plus countries occurred in the years 2008 and 2011. In these years, we can speak about a greater interconnection of the inverse character among the regions of the selected countries. It holds that in these two years negative changes in the number of employees in one region result in a positive change in their number in another region. Thus, we can speak about increased employee turnover among the selected countries. This, of course, is related to the inverse change in the incomes among the individual regions, or possibly to the change in the number of vehicles, too.

\section{Conclusion}

Many of our research findings still confirm that the socio-economic indicators such as higher income, lower unemployment, good health, education care, and environment or households equipment influence quality of life and economic development of not only regions but whole economies as well. Another very important finding is that these indicators (within regions) can also influence each other and can have positive or negative effects on them. 
This paper focused on the impact of economic, environmental, health and standard of living variables on the number of hospital staff on a sample of 46 NUTS II regions of Visegrad Group Plus countries in the period from 2004 to 2013. The aim of this paper was to estimate the impact of the selected socio-economic indicators on health personnel in monitored regions. Therefore, a simple econometric model was developed in which other indicators of the socio-economic sphere determine the number of health personnel.

We have determined whether our original statement, using the econometric model, will be confirmed: a positive effect on the healthcare staff is the amount of income, the number of vehicles, the medical beds, the motorways and the number of nights spent in the tourist facilities and their capacities. On the other hand, we assumed that the unemployment rate, infant mortality and waste affect the development of the number of healthcare staff negatively. According to the statistical test some of the indicators had to be excluded from our analysis and finally seven of the original ten indicators were included in the model.

Our results show that individual wealth has the greatest positive effect on the increase in the number of health personnel in the regions of the monitored countries due to higher household incomes, and also on the increase in the standard of living as a result of an increasing stock of vehicles. This applies to both the total population and per capita. Other significant indicators affect the number of healthcare employees to a much lesser extent. On the other hand, the changes in the number of health personnel in the previous period has a strong negative impact for all the variables monitored, i.e. both for the total population in the regions and for the conversion per capita, or for the female to male ratio of hospital staff.

Furthermore, in terms of gender, we found that the standard of living (stock of vehicles) had a deeper influence on the change of female hospital personnel. This may be due to the need for higher mobility for women, who provide household services and thus need to be more mobile than men are. Otherwise, changes in the number of male hospital personnel are influenced by the level of income.

An interesting result is that significant negative period (fixed) effects occurred only in two years, 2008 and 2011. We believe that these effects were based on the economic situation in the regions in the pre-crisis and post-crisis period from the view of the global financial crisis, which is always related to a subconscious, automatic need to improve the living standards of economic subjects.

Our research can contribute to the discussion about the regional economic level respectively development and the related regional competitiveness in terms of the socioeconomic approach. It can also provide a common ground for a further discussion on its measurement and the use of appropriate indicators. We hoped that this method could be able to complement the rising number of studies concerning the measurement of socioeconomic development.

In our further research, we intend to focus on the extension of our examination of the interaction among socio-economic indicators to all the regions of the European Union, with the intention of tracing the intensity and similarity of these relationships, depending on the economic level of these regions. 
Funding: This work was supported by the grant project CZ.02.1.01/0.0/0.0/17_049/0008452 "SMART Technologies to Improve the Quality of Life in Cities and Regions“.

Disclosure statement: No potential conflict of interest was reported by the author.

\section{References}

AKINCI, D. A, MATOUSEK, R., RADIĆ, N. \& STEWARD, CH. (2013). Monetary policy and the banking sector in Turkey. Journal of International Financial Markets, Institutions \& Money, 27, pp. 269-285. DOI: 10.1016/j.intfin.2013.08.001.

ANAND, S. \& BÄRNIGHAUSEN, T. (2004). Human resources and health outcomes: cross-country econometric study. The Lancet, 364(9445), pp. 1603-1609. DOI: $\underline{10.1016 / \mathrm{S} 0140-6736(04) 17313-3 .}$

ARELLANO, M. \& BOND, S. (1991). Some tests of specification for panel data: Monte Carlo evidence and an application to employment equations. Review of Economic Studies. 58(2), pp. 277-297. DOI: 10.2307/2297968.

ARTL, J. \& MANDEL, M. (2014). The Reaction Function of Three Central Banks of Visegrad Group. Prague Economic Papers, 3, pp. 269-289. DOI: 10.18267/j.pep.484

BARROS, C. P. \& NUNES, F. (2007). Governance and CEO pay and performance in non- profit organizations. International Journal of Social Economics. 34(11), pp. 811827. DOI: $10.1108 / 03068290710826404$.

BERWICK, D. M. \& HACKBARTH, A. D. (2012). Eliminating Waste in US Health Care. JAMA. 307(14), pp. 1513-1516. DOI: 10.1001/jama.2012.362.

BLOOM, D. AND CANNING, D. (2003). Health as Human Capital and its Impact on Economic Performance. The Geneva Papers on Risk and Insurance. 28(2), pp. 304-315. DOI: $10.1111 / 1468-0440.00225$.

CHRISTIAN, B. RAY, D., BENYOUSSEF, A. \& TANAHASHI, T. (1977). Health and socio-economic development: An intersectoral model. Social Science \& Medicine, 11(2), pp. 63-69 DOI: 10.1016/0037-7856(77)90001-4.

CLAYTON, M., LINARES-ZEGARA, J. \& WILSON, J. O. S. (2015). Does debt affect health? Cross country evidence on the debt-health nexus. Social Science and Medicine. 130, pp. 51-58. DOI: 10.1016/j.socscimed.2015.02.002.

COMBER, A., BRUNSON, CH. \& RADBURN, R. (2011). A spatial analysis of variations in health access: linking geography, socio-economic status and access perceptions. International Journal of Health Geographics, pp. 10-44. DOI: 10.1186/1476-072X-10$\underline{44}$.

CROISSANT, Y., ROY, W. \& CANTON, J. (2013) Reducing urban public transport costs by tendering lots: a panel data estimation. Applied Economics. 45(26), pp. 37113722. DOI: $\underline{10.1080 / 00036846.2012 .730133}$. 
DAVIS, A. \& QUINLIVAN, G. (2006). A panel data analysis of the impact of trade on human development. The Journal of Socio-Economics. 35(5), pp. 868-876. DOI: 10.1016/j.socec.2005.11.048.

EUGENIO-MARTIN, J. L., MORALES, N. M. \& SCARPA, R. (2004). Tourism and Economic Growth in Latin American Countries: A Panel Data Approach. FEEM Working Paper No. 26.2004. Milano: FEEM.

EUROSTAT (2018). Regional Database. [Online]. Available from: http://ec.europa.eu/eurostat/web/regions/data/database [Accessed: 10th January 2018].

FINGLETON, B. (2003). European Regional Growth. Berlin Heidelberg: SpringerVerlag.

GABDRAKHMANOV, N. K. \& RUBTSOV, V. A. (2014). Tourist and Recreational Positioning of Tatarstan Republic: Cluster Analysis. World Applied Sciences Journal (Management, Economics, Technology and Tourism). 30, pp. 202-205. DOI: 10.5829/idosi.wasj.2014.30.mett.45.

GEISHECKER, I. (2012). Simultaneity bias in the analysis of perceived job insecurity and subjective well-being. Economics Letters. 116(3), pp. 319-321. DOI: 10.1016/j.econlet.2012.03.018.

HALKOS, G. E. (2003). Environmental Kuznets Curve for sulfur: evidence using GMM estimation and random coefficient panel data models. Environment and Development Economics. 8(4), pp. 581-601. DOI: 10.1017/S1355770X0300317.

HANSEN, L. P. (1982) Large Sample Properties of Generalized Method of Moments Estimators. Econometrica. 50(4), pp. 1029-1054. DOI: 10.2307/1912775.

HERYÁN, T. \& TZEREMES, P. G. (2017). The bank lending channel of monetary policy in EU countries during the global financial crisis. Economic Modelling. 67, pp. 10-22. DOI: 10.1016/j.econmod.2016.07.017.

IMERS, G. W. (2002) Generalized Method of Moments and Empirical Likelihood. Journal of Business and Economic Statistics. 20(4), pp. 493-506, DOI: 10.1198/073500102288618630.

ISSA, H. \& OUATTARA, B. (2005). The effect of private and public health expenditure on infant mortality rates: does the level of development matters. Damascus Univ. Journal. 28(1), pp. 21-37.

JALAN, J. \& RAVALLION, M. (1998). Are there dynamic gains from a poor-area development program? Journal of Public Economics. 67(1), pp. 65-85. DOI: 10.1016/S0047-2727(97)00052-2.

KING, D. (2012). Hospital-adjacent hotels get built amid development standstill. [Online]. Available from: https://www.travelweekly.com/Travel-News/HotelNews/Hospital-adjacent-hotels-get-built-amid-development-standstill [accessed 20 October 2018]. 
MAJEROVA, I. (2017). Composite Development Index of Visegrad Group Regions. Working Paper in Interdisciplinary Economics and Business Research no. 45. Silesian University in Opava, School of Business Administration in Karviná.

MAJEROVA, I. (2018). Regional Development in Visegrad Group Countries and its Measurement. DETUROPE, 10(2), pp. 17-37.

MAJEROVA, I., \& NEVIMA, J. (2017). The measurement of human development using the Ward method of cluster analysis. Journal of International Studies, 10(2), pp. 239-257. DOI: $10.14254 / 2071-8330.2017 / 10-2 / 17$.

MCKEE, M. (2004). Reducing hospital beds: what are the lessons to be learned? Policy brief no. 6. European Observatory on Health Systems and Policies. Copenhagen: WHO Regional Office for Europe.

MICHAUD, P-C. \& VAN SOEST, A. (2008). Health and wealth of elderly couples: Causality tests using dynamic panel data models. Journal of Health Economics. 27(5), pp. 1312-1325. DOI: 10.1016/j.jhealeco.2008.04.002.

MOURAO, P. R. (2016). Socio-economic Determinants for the Portuguese Immigration: An Empirical Discussion. Social Indicators Research. 125(3), pp. 955-975. DOI: 10.1007/s11205-015-0860-6.

MULDOON, K. A., GALWAY, L. P., NAKAJJIMA, M., KANTERS, S., HOGG, R. S., BENDAVID, E. \& MILLS, E. J. (2011). Health system determinants of infant, child and maternal mortality: A cross-sectional study of UN member countries. Global Health.

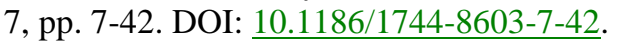

MULLAHY, J. \& SINDELAR, J. (1996). Employment, unemployment, and problem drinking. Journal of Health Economics. 15(4), pp. 409-434. DOI: 10.1016/S01676296(96)00489-4.

NG, T. H., LYE, CH. T. \& LIM, Y. S. (2013). Broadband penetration and economic growth in ASEAN countries: a generalized method of moments approach. Applied Economics Letters. 20(9), pp. 857-862. DOI: 10.1080/13504851.2012.754538.

NIELSEN, H. B. (2005) Generalized Method of Moments Estimation. [Online]. Available from:

URL https://www.econ.ku.dk/metrics/Econometrics2_05_II/.../gmm.pdf [accessed 10 January 2018].

NIJKAMP, P. \& ABREU, M. (2009). Regional Development Theory. [Online]. Available from: http://econpapers.repec.org/paper/vuawpaper/2009-29.htm [accessed 10 January 2018].

PÉREZ, E. A. \& NADAL, J. R. (2005). Host Community Perceptions A Cluster Analysis. Annals of Tourism Research. 32(4), pp. 925-941. DOI: 10.1016/j.annals.2004.11.004.

ROODMAN, D., 2009. How to do xtabond2: an introduction to difference and system GMM in Stata. The Stata Journal, 9(1), pp. 86-136. 
SAIDI, K. \& MAMMAMI, S. (2015). The impact of CO2 emissions and economic growth on energy consumption in 58 countries. Energy Reports. 1, pp. 62-70, DOI: 10.1016/j.egyr.2015.01.003.

SEMYONOV, M., LEWIN-EPSTEIN, N. \& MASKILEYSON, D. (2013). Where wealth matters more for health: The wealth-health gradient in 16 countries. Social Science and Medicine. 81, pp. 10-17. DOI: 10.1016/j.socscimed.2013.01.010.

SHAFIK, N. (1994). Economic Development and Environmental Quality: An Econometric Analysis. Oxford Economic Papers. 46(0) Special Issue on Environmental Economics, pp. 757-773. DOI: 10.1093/oep/46.Supplement 1.757.

SMITH, J. P. (1999). Healthy Bodies and Thick Wallets: The Dual Relation between Health and Economic Status. $J$ Econ Perspect. 13(2), pp. 144-166. DOI: $\underline{10.1257 / \text { jep.13.2.145 }}$

UNITED NATIONS (1983). European Agreement on main international traffic arteries (AGR) (with annexes and list of roads). Concluded at Geneva on 15 November 1975. Multilateral, vol. 1302, I-21618. Geneva: United Nations.

VERNER, T. \& CHUDARKOVA, S. (2013). Production Function and Human Capital: The Case of Visegrad Countries. In: H. Vojackova, ed. Proceedings of 31st International Conference on Mathematical Methods in Economics. Jihlava: College of Polytechnics Jihlava, pp. 321-325.

WHO (2016a). Health Employment and Economic Growth: A Five-Year Action Plan (2017-21). [Online]. Available from: http://www.who.int/hrh/com-heeg/comheeg_actionplan2016.pdf [accessed 10 November 2018].

WHO (2016b). Working for health and growth: investing in the health workforce. Report of the High-Level Commission on Health Employment and Economic Growth. Geneva: WHO.

ZHANG., CH. \& ZHUANG, L. (2011). The composition of human capital and economic growth: Evidence from China using dynamic panel data analysis. China Economic Review. 22(1), pp. 165-171. DOI: 10.1016/j.chieco.2010.11.001.

ZURN P., DAL POZ, M. O., STILWELL, B. \& ADAMS, O. (2004). Imbalance in the health workforce. Human Resources for Health, 2(13), pp. 595-600. DOI: $\underline{10.1186 / 1478-4491-2-13 .}$ 


\section{Appendix: Johansen Fisher Panel Cointegration Tests}

\section{Series: HE DC}

Sample: 20042013

Included observations: 460

\begin{tabular}{ccccc}
\hline \hline $\begin{array}{c}\text { Hypothesized } \\
\text { No. of CE(s) }\end{array}$ & $\begin{array}{c}\text { Fisher Stat. } \\
\text { (from trace test) }\end{array}$ & Prob. & $\begin{array}{c}\text { Fisher Stat. } \\
\text { (from max-eigen test) }\end{array}$ & Prob. \\
\hline \hline None & 148.9 & 0.0000 & 148.9 & 0.0002 \\
At most 1 & 762.2 & 0.0000 & 762.2 & 0.0000 \\
\hline \hline
\end{tabular}

* Probabilities are computed using asymptotic Chi-square distribution.

\section{Series: HE HB}

Sample: 20042013

Included observations: 460

\begin{tabular}{ccccc}
\hline \hline $\begin{array}{c}\text { Hypothesized } \\
\text { No. of CE(s) }\end{array}$ & $\begin{array}{c}\text { Fisher Stat.* } \\
\text { (from trace test) }\end{array}$ & Prob. & $\begin{array}{c}\text { Fisher Stat.* } \\
\text { (from max-eigen test) }\end{array}$ & Prob. \\
\hline \hline None & 166.0 & 0.0000 & 166.0 & 0.0000 \\
At most 1 & 728.1 & 0.0000 & 728.1 & 0.0000 \\
\hline \hline
\end{tabular}

* Probabilities are computed using asymptotic Chi-square distribution.

\section{Series: HE IN}

Sample: 20042013

Included observations: 460

\begin{tabular}{ccccc}
\hline \hline $\begin{array}{c}\text { Hypothesized } \\
\text { No. of CE(s) }\end{array}$ & $\begin{array}{c}\text { Fisher Stat. } \\
\text { (from trace test) }\end{array}$ & Prob. & $\begin{array}{c}\text { Fisher Stat. } \\
\text { (from max-eigen test) }\end{array}$ & Prob. \\
\hline \hline None & 183.0 & 0.0000 & 183.0 & 0.0000 \\
At most 1 & 762.2 & 0.0000 & 762.2 & 0.0000 \\
\hline \hline
\end{tabular}

* Probabilities are computed using asymptotic Chi-square distribution. 


\section{Series: HE TB}

Sample: 20042013

Included observations: 460

\begin{tabular}{ccccc}
\hline \hline $\begin{array}{c}\text { Hypothesized } \\
\text { No. of CE(s) }\end{array}$ & $\begin{array}{c}\text { Fisher Stat. }^{*} \\
\text { (from trace test) }\end{array}$ & Prob. & $\begin{array}{c}\text { Fisher Stat.* } \\
\text { (from max-eigen test) }\end{array}$ & Prob. \\
\hline \hline None & 148.9 & 0.0002 & 148.9 & 0.0002 \\
At most 1 & 796.2 & 0.0000 & 796.2 & 0.0000 \\
\hline \hline
\end{tabular}

* Probabilities are computed using asymptotic Chi-square distribution.

\section{Series: HE VH}

Sample: 20042013

Included observations: 460

\begin{tabular}{ccccc}
\hline \hline $\begin{array}{c}\text { Hypothesized } \\
\text { No. of CE(s) }\end{array}$ & $\begin{array}{c}\text { Fisher Stat. } \\
\text { (from trace test) }\end{array}$ & Prob. & $\begin{array}{c}\text { Fisher Stat.* } \\
\text { (from max-eigen test) }\end{array}$ & Prob. \\
\hline \hline None & 166.0 & 0.0000 & 166.0 & 0.0000 \\
At most 1 & 677.0 & 0.0000 & 677.0 & 0.0000 \\
\hline \hline
\end{tabular}

* Probabilities are computed using asymptotic Chi-square distribution.

\section{Series: HE WS}

Sample: 20042013

Included observations: 460

\begin{tabular}{ccccc}
\hline \hline $\begin{array}{c}\text { Hypothesized } \\
\text { No. of CE(s) }\end{array}$ & $\begin{array}{c}\text { Fisher Stat. }^{*} \\
\text { (from trace test) }\end{array}$ & Prob. & $\begin{array}{c}\text { Fisher Stat.* } \\
\text { (from max-eigen test) }\end{array}$ & Prob. \\
\hline \hline None & 183.0 & 0.0000 & 183.0 & 0.0000 \\
At most 1 & 728.1 & 0.0000 & 728.1 & 0.0000 \\
\hline \hline
\end{tabular}

* Probabilities are computed using asymptotic Chi-square distribution. 